\title{
Effect of shading in physiological responses, milk yield and quality of Girolando cows
}

\author{
Efeito do sombreamento nas respostas fisiológicas, produção e qualidade do leite de vacas
}

Girolando

Efecto del sombreado en las respuestas fisiológicas, producción y calidad de la leche de vacas

Girolando

Received: 01/14/2021 | Reviewed: 01/18/2021 | Accept: 01/19/2021 | Published: 01/24/2021

\author{
Mariana Borges de Castro Dias \\ ORCID: https://orcid.org/0000-0003-1544-9698 \\ Instituto Federal de Educação Ciência e Tecnologia Goiano, Brazil \\ E-mail: marianaborges@confinamentosaolucas.com.br \\ Karen Martins Leão \\ ORCID: https://orcid.org/0000-0001-5236-7558 \\ Instituto Federal de Educação Ciência e Tecnologia Goiano, Brazil \\ E-mail:karen.leao@ifgoiano.edu.br \\ Marco Antônio Pereira da Silva \\ ORCID: https://orcid.org/0000-0002-3875-1104 \\ Instituto Federal de Educação Ciência e Tecnologia Goiano, Brazil \\ E-mail: marco.antonio@ifgoiano.edu.br \\ Karen Sofia R. Santos \\ ORCID: https://orcid.org/0000-0002-1971-3356 \\ Instituto Federal de Educação Ciência e Tecnologia Goiano, Brasil \\ E-mail: karensofty@hotmail.com \\ Francisco Ribeiro de Araújo Neto \\ ORCID: https://orcid.org/0000-0002-6072-4997 \\ Instituto Federal de Educação Ciência e Tecnologia Goiano, Brazil \\ E-mail: netozoo@hotmail.com \\ José Flávio Neto \\ ORCID: https://orcid.org/0000-0001-6869-3374 \\ Instituto Federal de Educação Ciência e Tecnologia Goiano, Brazil \\ E-mail: jose.flavio@ifgoiano.edu.br \\ Thaisa Campos Marques \\ ORCID: https://orcid.org/0000-0003-1112-6699 \\ Instituto Federal de Educação Ciência e Tecnologia Goiano, Brazil \\ E-mail: thaisacm@hotmail.com \\ Edmar Soares Nicolau \\ ORCID: https://orcid.org/0000-0002-2512-3918 \\ Universidade Federal de Goiás, Brazil \\ E-mail: rena@cpa.evz.ufg.br
}

\begin{abstract}
The aim of this study was to evaluate the effect of providing shade to Girolando cows on milk yield and composition, physiological parameters, hemogram and blood $\mathrm{pH}$. Two treatments were used: paddocks with and without shade. Animals were alternately kept in each treatment for a period of 15 days for three times. Milk production was recorded and measurements were taken for rectal temperature, skin surface and udder surface temperatures. A total of 24 blood samples were collected form each cow during the experimental procedure. This was done to compare the mean milk yield and chemical composition as well as physiological and blood parameters. The t-test was applied at 5\% significance level. Milk urea was higher when the animals were kept in a shaded area. The morning recording for blood erythrocyte counts hematocrit, milk urea, rectal temperature, skin surface and udder surface temperatures showed interaction with respect to temperature ranges whereas the udder temperature in the afternoon showed a similar response. Girolando cows with 3/4 Holland + 1/4 Gyr and 7/8 Holland + 1/8 Gyr blood levels present an ability to adapt to the environment, and there was no effect of shading on milk yield and composition, physiological and blood parameters evaluated.
\end{abstract}

Keywords: Chemical composition of milk; Crossbred cows; Environment; Physiology; Thermal stress.

\section{Resumo}

O objetivo deste estudo foi avaliar o efeito de proporcionar sombra às vacas Girolando na produção e composição do leite, parâmetros fisiológicos, hemograma e pH do sangue. Utilizou-se dois tratamentos: piquetes com e sem sombra. Os animais foram mantidos alternadamente em cada tratamento por um período de 15 dias por três vezes. A produção 
de leite foi registrada e as medidas foram tomadas para temperatura retal, superfície da pele e temperatura da superfície do úbere. Coletou-se 24 amostras de sangue de cada vaca durante o procedimento experimental. Isso foi feito para comparar a produção média de leite e a composição química, bem como os parâmetros fisiológicos e sanguíneos. O teste t foi aplicado com nível de significância de 5\%. A ureia no leite foi maior quando os animais foram mantidos em piquetes sombreados. A registro matutino para contagem de eritrócitos no sangue, hematócrito, ureia no leite, temperatura retal, superfície da pele e temperatura da superfície do úbere mostrou interação em relação às faixas de temperatura, enquanto a temperatura do úbere à tarde mostrou uma resposta semelhante. As vacas Girolando com níveis sanguíneos 3/4 Holandês + 1/4 Gir e 7/8 Holandês + 1/8 Gir apresentam capacidade de adaptação ao ambiente, e não houve efeito do sombreamento na produção e composição do leite, parâmetros fisiológicos e sanguíneos avaliados.

Palavras-chave: Ambiência; Composição química do leite; Estresse térmico; Fisiologia; Vacas mestiças.

\section{Resumen}

El objetivo de este estudio fue evaluar el efecto de dar sombra a las vacas Girolando sobre el rendimiento y la composición de la leche, los parámetros fisiológicos, el hemograma y el pH de la sangre. Se utilizaron dos tratamientos: piquetes con y sin sombra. Los animales se mantuvieron alternativamente en cada tratamiento durante un período de 15 días durante tres veces. Se registró la producción de leche y se tomaron medidas de temperatura rectal, temperatura de la superficie de la piel y ubre. Se recolectó un total de 24 muestras de sangre de cada vaca durante el procedimiento experimental. Esto se hizo para comparar el rendimiento medio de la leche y la composición química, así como los parámetros fisiológicos y sanguíneos. La prueba t se aplicó a un nivel de significación del $5 \%$. La leche de urea fue mayor cuando los animales se mantuvieron en un área sombreada. El registro matutino de cómputo de eritrocitos en hematocrito de sangre, urea de leche, temperatura rectal, superficie de la piel y temperatura de la superficie de la ubre mostró interacción con respecto a los rangos de temperatura, mientras que la temperatura de la ubre en la tarde mostró una respuesta similar. Las vacas Girolando con grados sanguíneos 3/4 Holstein + 1/4 Gyr y 7/8 Holstein + 1/8 Gyr presentan una capacidad de adaptación al medio ambiente, y no hubo efecto del sombreado sobre el rendimiento y la composición de la leche, los parámetros fisiológicos y sanguíneos evaluado.

Palabras clave: Ambiente; Composición química de la leche; Estrés térmico; Fisiología; Vacas cruza.

\section{Introduction}

Thermal stress is one of the main factors involved in the decline in yield of lactating cows and dairy animals develop a series of adaptations in the respiratory, circulatory, endocrine, nervous and excretory systems to facilitate heat loss in hot climates (Marai \& Haeeb, 2010). Dairy cows accumulate a large amount of metabolic heat and low body cooling capacity, causes the heat load to rise to a point where body temperature increases, food intake decreases, and yield is compromised (West, 2003).

Some factors are observed to determine the ability of animals to tolerate thermal stress, e.g., physiological parameters, such as rectal temperature, but this can be influenced by age, breed, physiological state, time of day, food and water intake, ambient temperature, wind speed and season (Perissinoto \& Moura, 2007).

The hematological parameters are allied in the investigation of cases of thermal stress in animals (Paes et al., 2003). Serum analysis allows to obtain several information on the health status of the animals, used as a reliable indicator of thermal stress by the quantitative changes in the serum components (Kim et al., 2018).

Given the above, the objective of this study was to evaluate the effect of paddocks with and without shade on milk yield and quality of Girolando cows through the evaluation of milk chemical composition and somatic cell counts (SCC), as well as to evaluate the effect of paddocks with and without shade on physiological parameters of the animals, such as rectal temperature and skin and udder surface temperatures, hemogram and blood $\mathrm{pH}$.

\section{Methodology}

The present research is a quantitative, experimental and applied with explanatory purpose (Pereira et al., 2018), since the data collection was statistically analyzed to verify the relationship between variables.

The project was approved by the Ethics Committee on the use of animals of the IF Goiano with approval protocol 
number 8291310516. The experiment was carried out at the Instituto Federal Goiano - Rio Verde Campus, Latitude $17^{\circ} 48^{\prime} 49,273$ ' S, Longitude 5053'53,938' W and Altitude of 702 meters.

\section{Animals}

Nine Girolando cows with a blood level of 3/4 Holand + 1/4 Gyr and 7/8 Holand + 1/8 Gyr were used. During the experimental period, weekly samples of the diet supplied to the animals were collected for later chemical analysis according to the methodology previously described (D. J. Silva \& Queiroz, 2002). The animals received the same diet containing $29.2 \%$ dry matter (DM), $6.10 \%$ crude protein (CP), $4.80 \%$ ether extract (EE), $60.7 \%$ neutral detergent fiber (NDF), $41.3 \%$ acid detergent fiber (ADF), 37\% crudes fiber (CF) and 74\% total digestible nutrients (TDN).

The animals were mechanically milked at $7 \mathrm{~h} 30 \mathrm{~min}$ am and $3 \mathrm{~h} \mathrm{pm}$, in a Herringbone parlor. The animals were brought to the waiting room $\left(408 \mathrm{~m}^{2}\right.$, concrete floor and $80 \%$ shade cloth), without water and feed availability. The animals waited for about 30 minutes, the time for each animal being variable according to the order of entry into the milking parlor.

\section{Experimental procedure}

Cows were subjected to two treatments: a paddock with shade (shading cloth, constituted of plastic canvas with provision of $80 \%$ shade, with $8.0 \mathrm{~m} 2$ per animal and 121 linear meters of trees) and a paddock without shade. The 90 experimental days were divided in 6 periods of 15 days in which the animals alternately kept for three periods in the paddock with access to the shade and three periods in the paddock without shade. Therefore, the animals were subjected three times to each treatment; the first seven days for adaptation and remaining eight days for data collection and sampling.

Throughout the experimental period, a daily measurement of the ambient temperatures and maximum and minimum humidity in the paddock with and without shade and inside the milking parlor was taken with the aid of a thermo-hygrometer. The thermo-hygrometer in the paddock with shade was located below the shading cloth, and the thermo-hygrometer in the paddock without shade was exposed to the sun. The temperature and humidity of the milking parlor were recorded daily at the time of the two milking with the temperature expressed in ${ }^{\circ} \mathrm{C}$, and humidity in percentage. During the experimental period, the daily temperature and humidity index (THI) was calculated according to the model previously used (Marques et al., 2014), with $\mathrm{THI}=0.8 \times \mathrm{T}+[(\mathrm{RH}(\%) / 100) \times(\mathrm{T}-14.4)]+46.4$, where $\mathrm{T}$ is the temperature in ${ }^{\circ} \mathrm{C}$ and $\mathrm{RH}$ is the relative air humidity, measured by a digital thermo-hygrometer (Instrutemp, Belenzinho, São Paulo, Brazil).

From the eighth to the fifteenth day of each period, daily at $7 \mathrm{~h} 30 \mathrm{~min}$ and $13 \mathrm{~h}$, the rectal temperature and surface temperature of the skin and udder of each animal was measured. Rectal temperature was measured by a rectal veterinary thermometer inserted into the rectum of the animals for two minutes and the result was expressed in degrees Celsius.

The skin surface temperature was measured using an infrared digital thermometer with laser sight positioned at two meters from each animal and pointed to the lower part of the last rib. The udder temperature measurement followed the same protocol with the thermometer pointing straight to the udder skin without signs of superficial veins and arteries. Both results were expressed in degrees Celsius. This procedure was carried out during the whole sampling period at both milking times. Totaling 216 rectal, skin and udder temperature measurements per treatment in the morning and afternoon.

\section{Blood analysis}

At each sampling and data collection period, in four intercalated days, blood samples were taken for blood $\mathrm{pH}$ and complete hemogram analyses. A total of 108 blood samples per treatment were collected during the 90 experimental days. Blood was collected by venipuncture of the subcutaneous abdominal vein using sterile vacuum needles $(25 \mathrm{x} 0.8 \mathrm{~mm})$ and BD Vacutainer® tubes with EDTA K3 anticoagulant. The determination of the $\mathrm{pH}$ was performed immediately after the collection 
through ION pHB $500 \mathrm{pHmeter}$. The electrode was immersed in blood samples from each animal and the value of each sample was recorded. For the hemogram, blood samples were kept in an isothermal box with ice until the arrival at the laboratory. The erythrocyte counts were performed in a modified Neubauer chamber by dilution of the cells using a 20-microliter semiautomatic pipette. For the determination of hematocrit, the microhematocrit technique was used for 15 minutes, using homogeneous capillary tubes of $75 \mathrm{~mm}$ in length by $1 \mathrm{~mm}$ in diameter. The determination of blood hemoglobin content was performed using the cyanmethemoglobin method using an automatic biochemical analyzer, Bioplus 2000, with the aid of the commercial hemoglobin test kit, Labtest Diagnóstic $®$. The absolute hematimetric indices: mean globular volume (MGV) and mean globular hemoglobin concentration (MGHC) were obtained by counting the number of erythrocytes, hematocrit and hemoglobin content.

\section{Milk analysis}

From the eighth to the fifteenth day of each period, weighing and individual collection of milk of the animals were daily performed on the morning and afternoon milkings, using individual meters. The milk for each animal, previously identified with a bar code, was collected in a Bronopol@ preservative bottle $(40 \mathrm{~mL})$, with a volume of $2 / 3$ at the morning milking and $1 / 3$ at the afternoon milking, totaling 216 milk samples per treatment, collected during 90 experimental days. After collection, milk samples were stored in isothermal boxes containing ice, sent to the Universidade Federal de Goiás, and the electronic analyses were carried out and the final report was issued with the results. The contents of fat, protein, lactose, defatted dry extract (DDE) and total dry extract (TDE) were determined according to the standard ISO 9622 (IDF, 2013). Results were expressed as percentage (\%). The urea (mg.dL-1) and casein $(\%)$ contents were determined by differential absorption of infrared waves, transformed by Fourier-FTIR, using the Lactoscope equipment (Delta Instruments). SCC was determined by flow cytometry according to ISO 13366-2 (IDF, 2006). The results were expressed in SC.mL-1.

\section{Statistical analysis}

Milk yield and chemical composition, rectal temperature, skin and udder surface temperatures, erythrocytes, hemoglobin, hematocrit, mean globular volume, mean globular hemoglobin, platelets, leukocytes and blood pH were analyzed by t-test at 5\% significance level, using Assistat Software (Silva \& Azevedo, 2016). To evaluate the interaction effect between different temperature ranges and treatments, modeling was performed using mixed models. The individual effect of the animal was considered as random, in view of the repeated measures taken. The SAS software (SAS, 2004) was used and considered in all hypothesis tests a significance level of $5 \%$ probability.

\section{Results}

Through the results obtained in the present study, it can be said that the rectal temperatures found in the treatments, $37.7^{\circ} \mathrm{C}$ and $38.4^{\circ} \mathrm{C}$ for cows kept in shade, and $37.6^{\circ} \mathrm{C}$ and $38.4^{\circ} \mathrm{C}$ for cows without access to shade, in the morning and afternoon periods, respectively.

The temperatures and the maximum and minimum humidity of the shaded and unshaded paddocks and milking parlor are listed in Table 1. 
Table 1. Means and standard error of maximum and minimum temperature $\left({ }^{\circ} \mathrm{C}\right)$ and humidity $(\%)$ of paddocks with and without shade and milking parlor.

\section{Cows kept in shade}

\section{Cows kept without shade}

\begin{tabular}{lcccc}
\hline Temperature & Minimum & Maximum & Minimum & Maximum \\
\hline Paddock with shade & $13.3 \pm 0.51$ & $34.4 \pm 0.52$ & $13.9 \pm 0.52$ & $35.3 \pm 0.52$ \\
Paddock without shade & $13.4 \pm 1.00$ & $37.8 \pm 0.83$ & $15.1 \pm 1.00$ & $37.9 \pm 0.82$ \\
Milking parlor & $17.0 \pm 0.70$ & $28.5 \pm 0.46$ & $17.6 \pm 0.70$ & $30.1 \pm 0.46$ \\
\hline & Cows kept in shade & Maximum kept without shade & Maximum \\
\hline Humidity & Minimum & Minimum & $31.5 \pm 3.16$ & $64.1 \pm 3.08$ \\
\hline Paddock with shade & $48.7 \pm 4.25$ & $69.5 \pm 2.07$ & $43.9 \pm 3.91$ & $74.7 \pm 2.02$ \\
Paddock without shade & $52.9 \pm 4.23$ & $76.9 \pm 2.08$ & $38.1 \pm 1.93$ & $72.7 \pm 1.52$ \\
Milking parlor & $47.6 \pm 2.48$ & $71.9 \pm 1.60$ & &
\end{tabular}

No significant difference at $5 \%$ probability $(\mathrm{P}<0.05)$. Fonte: Autores.

The temperature and humidity of the milking parlor at the time of milking are presented in Table 2. The maximum THI during the experimental period in which animals remained in the paddock with and without shade was 87.8 and 87.9 , respectively.

Table 2. Means and standard error of temperature $\left({ }^{\circ} \mathrm{C}\right)$ and humidity $(\%)$ of the milking parlor at 7:30 a.m. and 3 p.m.

\begin{tabular}{lcc}
\hline Temperature & Cows kept in shade & Cows kept without shade \\
\hline 7:30 a.m. & $18.3 \pm 0.31$ & $19.8 \pm 0.68$ \\
3 p.m. & $27.5 \pm 0.43$ & $28.6 \pm 0.56$ \\
\hline Humidity & Cows kept in shade & Cows kept without shade \\
\hline 7:30 a.m. & $63.9 \pm 1.58$ & $64.9 \pm 1.57$ \\
3 p.m. & $42.7 \pm 2.32$ & $42.5 \pm 2.13$ \\
\hline
\end{tabular}

No significant difference at $5 \%$ probability $(\mathrm{P}<0.05)$. Fonte: Autores.

Evaluating the skin temperature, it was observed that there was variation between the treatments only in the morning, and the treatment with shade obtained $31.8^{\circ} \mathrm{C}$, and without shade, $32.1^{\circ} \mathrm{C}$ (Table 3 ).

Table 4 presents the results of the hemogram and blood $\mathrm{pH}$; these parameters did not differ between treatments. The blood $\mathrm{pH}$ in both treatments presented an average of 7.95 , tending to alkalinity.

There was no difference in milk yield between treatments, as can be seen in Table 5 . 
Table 3. Means and standard error of rectal temperature (RT), skin surface temperature (SST) and udder surface temperature (UST) of Girolando lactating cows kept in paddocks with and without shade at 7:30 a.m. and 3 p.m.

\begin{tabular}{lcc}
\hline & Cows kept in shade & Cows kept without shade \\
\cline { 2 - 3 } & & $\mathbf{7 : 3 0}$ a.m. \\
\hline $\mathrm{RT}\left({ }^{\circ} \mathrm{C}\right)$ & $37.7 \pm 0.02 \mathrm{a}$ & $37.6 \pm 0.02 \mathrm{a}$ \\
$\mathrm{SST}\left({ }^{\circ} \mathrm{C}\right)$ & $31.8 \pm 0.10 \mathrm{~b}$ & $32.1 \pm 0.07 \mathrm{a}$ \\
$\mathrm{UST}\left({ }^{\circ} \mathrm{C}\right)$ & $30.4 \pm 0.19 \mathrm{a}$ & $30.9 \pm 0.17 \mathrm{a}$ \\
\hline & & $38.4 \pm 0.05 \mathrm{a}$ \\
\hline $\mathrm{RT}\left({ }^{\circ} \mathrm{C}\right)$ & $38.4 \pm 0.02 \mathrm{a}$ & $34.1 \pm 0.08 \mathrm{a}$ \\
$\mathrm{SST}\left({ }^{\circ} \mathrm{C}\right)$ & $34.1 \pm 0.07 \mathrm{a}$ & $33.1 \pm 0.12 \mathrm{a}$ \\
$\mathrm{UST}\left({ }^{\circ} \mathrm{C}\right)$ & $33.4 \pm 0.13 \mathrm{a}$ & $\mathbf{3 . m}$ \\
\hline
\end{tabular}

Different letters in the same row indicate significant difference at $5 \%$ probability $(\mathrm{P}<0.05)$. Fonte: Autores.

Table 4. Mean and standard deviation of erythrocyte, platelet and leukocyte counts, hemoglobin, hematocrit, mean globular volume (MGV), mean globular hemoglobin (MGHC) and blood pH, of Girolando cows kept in paddocks with and without shade.

\begin{tabular}{lcc}
\hline Parameter & Cows kept in shade & Cows kept without shade \\
\hline Erythrocytes $\left(\mathrm{x} 10^{6} / \mathrm{mm}^{3}\right)$ & $6.20 \pm 0.02$ & $6.19 \pm 0.02$ \\
Hemoglobin $(\mathrm{g} / \mathrm{dL})$ & $10.2 \pm 0.13$ & $10.1 \pm 0.13$ \\
Hematocrit $(\%)$ & $30.6 \pm 0.4$ & $29.9 \pm 0.39$ \\
MGV $\left(\mu^{3}\right)$ & $49.2 \pm 0.58$ & $48.5 \pm 0.54$ \\
MGHC $(\mathrm{pg})$ & $16.5 \pm 0.19$ & $16.2 \pm 0.17$ \\
Platelets $\left(\mathrm{mm}^{3}\right)$ & $219409.8 \pm 1.59$ & $218168.2 \pm 1.34$ \\
Leukocytes $\left(\mathrm{mm}^{3}\right)$ & $13720.4 \pm 0.44$ & $13452.3 \pm 0.43$ \\
$\mathrm{pH}$ & $7.95 \pm 0.01$ & $7.95 \pm 0.02$ \\
\hline
\end{tabular}

No significant difference at $5 \%$ probability $(\mathrm{P}<0.05)$. Fonte: Autores.

Table 5. Mean and standard error of total milk yield $(\mathrm{kg})$, in the morning and afternoon, of Girolando cows kept in paddocks with and without shade.

\begin{tabular}{lcc}
\hline & Cows kept in shade & Cows kept without shade \\
\hline Morning (7 a.m.) & $7.23 \pm 0.49$ & $6.91 \pm 0.48$ \\
Afternoon (3 p.m) & $3.63 \pm 0.22$ & $3.55 \pm 0.25$ \\
Total & $10.9 \pm 0.70$ & $10.5 \pm 0.71$ \\
\hline
\end{tabular}

No significant difference at $5 \%$ probability $(\mathrm{P}<0.05)$. Fonte: Autores.

Urea presented higher values in the period when the cows were kept in the shade. The other milk parameters evaluated showed no difference (Table 6). 
Table 6. Mean and standard error of fat (\%), protein (\%), lactose (\%), total dry extract (TDE) (\%), defatted dry extract (DDE) (\%), somatic cell count (SCC x $\left.1000 \mathrm{~mL}^{-1}\right)$, concentration of urea (mg.dL ${ }^{-1}$ ) and casein (\%) of milk of Girolando dairy cows, kept in paddocks with and without shade.

\begin{tabular}{lcc}
\hline & Cows kept in shade & Cows kept without shade \\
\hline Fat & $3.46 \pm 0.04 \mathrm{a}$ & $3.49 \pm 0.05 \mathrm{a}$ \\
Proteina & $3.12 \pm 0.02 \mathrm{a}$ & $3.12 \pm 0.02 \mathrm{a}$ \\
Lactose & $4.09 \pm 0.04 \mathrm{a}$ & $4.05 \pm 0.05 \mathrm{a}$ \\
TDE & $11.7 \pm 0.07 \mathrm{a}$ & $11.67 \pm 0.10 \mathrm{a}$ \\
DDE & $8.24 \pm 0.05 \mathrm{a}$ & $8.18 \pm 0.07 \mathrm{a}$ \\
SCC & $238 \pm 14.3 \mathrm{a}$ & $282 \pm 18.7 \mathrm{a}$ \\
Urea & $10.8 \pm 0.27 \mathrm{a}$ & $9.93 \pm 0.23 \mathrm{~b}$ \\
Casein & $2.39 \pm 0.02 \mathrm{a}$ & $2.38 \pm 0.02 \mathrm{a}$ \\
\hline
\end{tabular}

Different letters in the same row indicate significant difference at $5 \%$ probability $(\mathrm{P}<0.05)$. Fonte: Autores.

\section{Discussion}

Rectal temperatures presented in this study the normal physiological variation patterns for dairy cattle, which is 38.6 to $39.4^{\circ} \mathrm{C}$ (Smith \& Risco, 2005). Similar to the results obtained, mean rectal temperature (fall and winter) of $38.2^{\circ} \mathrm{C}$ in Girolando ( $1 / 2$ Holland + 1/2 Gyr) was observed cows in tropical climate (Santos et al., 2018). The storage of body heat between the periods was not enough to cause hyperthermia, since the afternoon RT did not reach values higher than $39.3^{\circ} \mathrm{C}$, suggesting that the cows were able to dissipate body heat, maintaining thermal balance.

Blood $\mathrm{pH}$ was higher than normal (Table 4), since the neutral $\mathrm{pH}$ is around 7.4 (Severinghaus et al., 1998). In the present study, the $\mathrm{pH}$ presented a mean value of 7.95 tending to alkalinity, which may have been caused by an increase in the respiratory rate of the animals. Lactating cows (n=96) showed a pH of 7.4 (Fagnani et al., 2014), justifying that the acid-base state of the blood can be compensated by the renal and/or respiratory functions, because the blood pH must be within a very narrow range of variation so that the physiological functions occur correctly, and may justify the absence of alteration in the blood $\mathrm{pH}$ of the animals.

In this study there was no difference in milk yiekd, regardless of shading treatment (Table 5). Previous study (Façanha et al., 2010), analyzed ST in Holstein cows and observed that cows with higher milk yield had higher ST, in relation to cows with lower production, possibly due to higher metabolic activity and, consequently, greater internal heat generation, which is usually dissipated via body surface.

The results regarding the concentration of urea in milk found in this study were $10.8 \mathrm{mg} . \mathrm{dL}-1$ for cows with access to shade, and $9.93 \mathrm{mg}$.dL-1 for cows without access to shade (Table 6). The concentration of urea in milk is not linked to the regulation of homeostatic mechanisms (Gonzalez et al., 2004). Thus, the possible explanation for the results obtained on the levels of urea in milk, being higher when the animals were subjected to shade treatment may have been due to a higher food intake during this period, since the animals in thermal comfort tend to increase food intake, and consequently increase protein intake, and urea is the end product of protein metabolism by ruminants.

Possibly, the shading did not affect these physiological parameters more expressively (Table 6), due to the low metabolic activity and milk yield of the cows when kept with $(10.9 \mathrm{~kg})$ and without shade $(10.5 \mathrm{~kg})$. It can be said that these animals managed to maintain a balance between body temperature and the environment in which they were. It is known that for heat exchange processes to occur normally, the skin surface of lactating cows should have temperatures below $35^{\circ} \mathrm{C}$ 
(Collier et al., 2006). Another research (Santos et al., 2018) also did not observe effect of the climatic environment on milk production and physiological parameters (rectal and body surface temperature) of $1 / 2$ blood Gir cows with a mean yield of 15.09 $\mathrm{kg}$ milk, kept in a tropical climate.

The results reported in the literature on the influence of SCC on milk components are very divergent. In general, in cows with mastitis (a condition that increases SCC), the milk produced has a lower percentage of fat, but if milk yield decreases more sharply than the decrease in fat production, there will be a concentration of this component (Cinar et al., 2015). Higher content of fat and protein in the milk of animals kept in shade and higher levels of SCC in animals in the shade were found compared to animals in the sun, once the animals crowded together in the shade and causing the number of environmental pathogens to become greater (Barbosa et al., 2004).

\section{Conclusion}

In conclusion, Girolando cows with 3/4 Holland $+1 / 4$ Gyr and 7/8 Holland $+1 / 8$ Gyr blood levels with relatively low milk production potential under the experimental conditions tested, have an ability to adapt to the environment, since there was no effect of shade on milk yield and quality, physiological and blood parameters evaluated. Consequently, this type of Girolando cows can withstand climate change without affecting productive performance. Investigations regarding the expression of genes related to thermal stress should be carried out to further elucidate the potential of this breed for adverse environments.

\section{Acknowledgments}

Special thanks to Instituto Federal Goiano de Educação Ciência e Tecnologia Goiano for support and structure enabled to the project execution and CAPES for Master's scholarship.

\section{References}

Barbosa, O. R., Boza, P. R., Santos, G. T., Sakagushi, E. S., \& Ribas, N. P. (2004). Efeitos da sombra e da aspersão de água na produção de leite de vacas da raça Holandesa durante o verão. Acta Scientiarum. Animal Sciences, 26(1), 115-122. https://doi.org/10.4025/actascianimsci.v26i1.1961

Cinar, M., Serbester, U., Ceyhan, A., \& Gorgulu, M. (2015). Effect of somatic cell count on milk yield and composition of first and second lactation dairy cows. Italian Journal of Animal Science, 14(1), 105-108. https://doi.org/10.4081/ijas.2015.3646

Collier, R. J., Dahl, G. E., \& Vanbaale, M. J. (2006). Major advances associated with environmental effects on dairy cattle. Journal of Dairy Science, 89(4), 1244-1253. https://doi.org/10.3168/jds.S0022-0302(06)72193-2

Façanha, D. A. E., Silva, R. G., Maia, A. S. C., Guilhermino, M. M., \& Vasconcelos, A. M. (2010). Variação anual de características morfológicas e da temperatura de superfície do pelame de vacas da raça Holandesa em ambiente semiárido. Revista Brasileira de Zootecnia, 39(4), 837-844.

Fagnani, R., Beloti, V., \& Battaglini, A. P. P. (2014). Acid-base balance of dairy cows and its relationship with alcoholic stability and mineral composition of milk. Pesquisa Veterinaria Brasileira, 34(5), 398-402. https://doi.org/10.1590/S0100-736X2014000500002

Gonzalez, H. L., Fischer, V., Ribeiro, M. E. R., Gomes, J. F., Stumpf Jr, W., \& Silva, M. A. (2004). Avaliação da Qualidade do Leite na Bacia Leiteira de Pelotas, RS. Efeito dos Meses do Ano. Revista Brasileira de Zootecnia, 33(6), 1531-1543.

IDF. (2006). ISO 13366-2/IDF 148-2 - Milk - Enumeration of somatic cells - Part. 2: Guidance on the operation of fluoro-opto-electronic counters (2nd ed.).

IDF. (2013). ISO 9622/IDF 141C - Determination of milkfat, protein and lactose content - Guidance on the operation of mid-infrared instruments. (2nd ed.).

Kim, W. S., Lee, J. S., Jeon, S. W., Peng, D. Q., Kim, Y. S., Bae, M. H., Jo, Y. H., \& Lee, H. G. (2018). Correlation between blood, physiological and behavioral parameters in beef calves under heat stress. Asian-Australasian Journal of Animal Sciences, 31(6), 919-925. https://doi.org/10.5713/ajas.17.0545

Marai, I. F. M., \& Haeeb, A. A. M. (2010). Buffalo's biological functions as affected by heat stress - A review. Livestock Science, 127(2-3), 89-109. https://doi.org/10.1016/j.livsci.2009.08.001

Marques, T. C., Leão, K. M., Viu, M. A. O., \& Sartori, R. (2014). The effects of progesterone treatment following artificial insemination on the reproductive performance of dairy cows. Tropical Animal Health and Production, 46(2). https://doi.org/10.1007/s11250-013-0504-2 
Research, Society and Development, v. 10, n. 1, e45410111986, 2021

(CC BY 4.0) | ISSN 2525-3409 | DOI: http://dx.doi.org/10.33448/rsd-v10i1.11986

Paes, P. R. O., Lopes, S. T. A., Lopes, R. S., Kohayagawa, A., Takahira, R. K., \& Langon, H. (2003). Efeitos da administração de vitamina E na infecção mamária e na contagem de células somáticas de cabras primíparas desafiadas experimentalmente com Staphylococcus aureus. Arquivo Brasileiro de Medicina Veterinária e Zootecnia, 55(1), 15-20. https://doi.org/10.1590/S0102-09352000000300011

Pereira, A. S., Shitsuka, Dorlivete Moreira Parreira, F. J., \& Shitsuka, R. (2018). Metodologia da Pesquisa Científica. UAB/NTE/UFSM.

Perissinoto, M., \& Moura, D. J. (2007). Determinação Do Conforto Térmico De Vacas Leiteiras Utilizando a Mineração De Dados / Evaluation of Thermal Comfort in Dairy Cattle Using Data Mining. Revista Brasileira de Engenharia de Biossistemas, 1(2), 117. https://doi.org/10.18011/bioeng2007v1n2p117-126

Santos, L. V., Carvalho, C. C. S., Ruas, J. R. M., Diniz, T. A., Silva, E. A., \& Moreira, S. J. M. (2018). Impact of microclimate on the physiology, hair coat and milk production of dairy cows at different seasons. Revista de Ciencias Agroveterinarias, 17(3), 368-376. https://doi.org/10.5965/223811711732018368

SAS. (2004). SAS Enterprise guide Software (9.1). Institute Inc. Cary.

Severinghaus, J. W., Astrup, P., \& Murray, J. F. (1998). Blood gas analysis and critical care medicine. American Journal of Respiratory and Critical Care Medicine, 157, S114-112. https://doi.org/10.1164/ajrccm.157.4.nhlb1-9

Silva, D. J., \& Queiroz, A. C. (2002). Análise de alimentos: métodos químicos e biológicos (3rd ed.). UVF.

Silva, F. A. S., \& Azevedo, C. A. V. (2016). The Assistat Software Version 7.7 and its use in the analysis of experimental data. African Journal of Agricultural Research, 11(39), 3733-3740. https://doi.org/10.5897/ajar2016.11522

Smith, B. I., \& Risco, C. A. (2005). Management of periparturient disorders in dairy cattle. Veterinary Clinics of North America - Food Animal Practice, 21, 503-521. https://doi.org/10.1016/j.cvfa.2005.02.007

West, J. W. (2003). Effects of heat-stress on production in dairy cattle. Journal of Dairy Science, 86(6), 2131-2144. https://doi.org/10.3168/jds.S0022$0302(03) 73803-\mathrm{X}$ 